\title{
Assessment of decomposition rate of Acacia mangium litter for rehabilitating degraded mined sites
}

\author{
Alexander Baffour Afrifa \\ Kwame Nkrumah University of Science and Technology, Faculty of Forest Resources \\ Technology, Department of Social Forestry, Sunyani, Ghana.
}

\begin{abstract}
Acacia mangium, widely used to rehabilitate degraded mined sites, hasbeen reported to be slow in decomposition. The experiment was carried out to establish the rate of decomposition of Acacia mangiumleaf litter and determine the correlation between the stand age and decomposition rate ofits litter.Litter decomposition rate of Acacia mangium under monoculture plantation was studied using the wire mesh frame technique. Wire mesh frames containing $200 \mathrm{~g}$ of fresh Acacia mangium leaves were set up in three Acacia mangiumstands of ages five, seven and nine years. Ten wire mesh frames were left in each stand using Completely RandomizedDesign. The decay rate coefficient " $k$ " was used to determine the constant potential weight loss of the dry matter. The value of kwas estimated to be $0.0064,0.0049$ and 0.0039 for the $30^{\text {th }}, 60^{\text {th }}$ and $90^{\text {th }}$ days respectively, with overall mean of 0.0050 for all the stands. The Half-life estimated for all the stands was 140 days. Analysis of Variance at $5 \%$ significant level indicates significant difference between stand age in weight losses on the $30^{\text {th }}$ and $60^{\text {th }}$ daysbut no significant effect between the $60^{\text {th }}$ and $90^{\text {th }}$ days of observation; there were differences in the decomposition rate between the Acacia mangium leaf litter on the seven and nine years stands.
\end{abstract}

Keywords: Decomposition Rate, Decay Rate Coefficient, Half-Life

\section{INTRODUCTION}

As a result of increasing demand for mineral bearing lands (gold concession) and its resources, agricultural and forest lands have come under great pressure and methods to rehabilitate degraded lands have been a major concern to environmentalist.This calls for rehabilitation of degraded lands with fast growing species which can thrive well on very poor soil as it is the case in mined areas. Acaciamangium has been found to be fast growing species outperforming Albiziafalcataria, Gmelinaarborea considered among the fastest growing useful trees on earth (NAS, 1979).

Climatic variables, chemical composition of the litter and its palatability to soil fauna are most important determinants in the decomposition process (Van Cleve, 1974).The decomposition of litter and subsequent release of nutrients in plant-available forms is an essential process in the functioning of forest ecosystems. Temperature, moisture, and litter chemistry control decomposition rates through their influences on the activity of soil organisms. Forestry activities that influence the microclimate or nature of the litter can alter decomposition rates (Prescott, et al., 2000).

Although Acacia mangium is a fast growing species and mining companies have capitalized on this fact and are using it to rehabilitate degraded areas after mining operations, it appears the leaf litter is slow in decomposition. This may be due to the fact that, it produces abundant foliage especially in the dry season (Ngo and Nguyen, 1991), thereby accumulating more litter.Ecologists have paid considerable attention to litter decomposition in relation to nutrient cycling and soil productivity. The obvious reason is that litter decay has a pronounced effect on the availability of nutrients, and nutrient availability is a basic determinant of the tree growth and food production (Bunvonget al., 1978). The objectives of the project are to determine the rate of decomposition of Acacia mangium leaf litter and identification of the correlation between the age of the stand and the rate of decomposition of its litter.

\section{MATERIALS AND METHODS}

Acacia mangium leaf litter was used as the decomposing material during the 90 day study. Wire mesh frame of dimension $25 \mathrm{~cm} \times 25 \mathrm{~cm} \times 5 \mathrm{~cm}$ high 
with hole intervals of $2.5 \mathrm{~cm} \times 2.5 \mathrm{~cm}$ was used as the container of the decomposing material. The holes between the mesh frames allow direct interaction of decomposition materials with the environments. Electronic beam balance was used to measure the weight.Monoculture stands of 5,7 and 9 yearswere used as the treatment. In each of the age (treatment), ten of the frames containing $200 \mathrm{~g}$ fresh weight (60.26g dry weight) of the leaves collected from both mature and young Acacia mangium trees were monitored. The leaves were uniformly spread in the frames to ensure maximum interaction with the environment. The duration of the study was 90 days, with sampling days of 30,60 and 90 . At every 30,60 and 90 days two replicates were collected at random from each of the treatments (age stand). The samples in the frame were oven dried in laboratory at $67^{\circ} \mathrm{C}$ until constant weight attained. The dry matter weight of the litter were determined on an electronic beam balance and recorded for all the sampling days. The decay rate coefficient was worked out for the constant potential weight loss by using theformula suggested by Olson, (1963). That is, $X t / X_{0}=e^{-k t}$ where, $X t=$ the weight remaining at time't' $(g), X_{0}=$ original weight $(\mathrm{g}), \mathrm{e}=$ base of natural Logarithm, $k=$ decay rate coefficient and $t=$ time. Half-life of the litter was calculated using the Formula

$: t_{50}=-\underline{\ln (0.5)}$

$k$ was estimated for each period (30,60 and 90 days) and the average $k$ used for half-lifeestimation.The data was analysed using Analysis of variance at $5 \%$ significant level. Least square difference was used to separate treatments that were different significantly and the results presented in tables and graph.

\section{RESULTS}

\section{Pattern and the rate of decomposition of the five- year stand}

From an initial weight of $60.26 \mathrm{~g}$ to $47.55 \mathrm{~g}$ in 30 days a difference of $12.71 \mathrm{~g}$ and from $47.55 \mathrm{~g}$ to $43.31 \mathrm{~g}$ in 60 days a difference of $4.24 \mathrm{~g}$ and from $43.31 \mathrm{~g}$ to $38.81 \mathrm{~g}$ in 90 days a difference of $4.5 \mathrm{~g}$ was recorded (Fig 1). It could be observed that there was a continuous weight loss in the course of time. From an initial rapid phase in the first 30 days to a slower phase in the latter days. The decay rate coefficient $k$ was worked out to study the constant potential weight loss. The value of $k$ was estimated to be 0.0078 for the $30^{\text {th }}$ day, 0.0055 for the $60^{\text {th }}$ day and 0.0048 for the $90^{\text {th }}$ day.
Pattern and the rate of decomposition of the seven-year stand: From an initial weight of $60.26 \mathrm{~g}$ to $46.66 \mathrm{~g}$ in 30 days a difference of $13.60 \mathrm{~g}$ and from $46.66 \mathrm{~g}$ to $44.44 \mathrm{~g}$ in 60 days a difference of $2.22 \mathrm{~g}$ and from $44.44 \mathrm{~g}$ to $40.68 \mathrm{~g}$ in 90 days a difference of $3.76 \mathrm{~g}$ (Fig 1). It could be observed that there was a continuous weight loss in the course of time. From an initial rapid phase in the first 30 days to a slower phase in the later days. The decay rate coefficient $k$ was worked out to study the constant potential weight loss. The value of $k$ was estimated to be 0.0085 for the $30^{\text {th }}$ day, 0.0050 for the $60^{\text {th }}$ day and 0.0043 for the $90^{\text {th }}$ day.

Pattern and the rate of decomposition of the nineyear stand: From an initial weight of $60.26 \mathrm{~g}$ to $54.63 \mathrm{~g}$ in 30 days a difference of $5.63 \mathrm{~g}$ and from $54.63 \mathrm{~g}$ to $47.67 \mathrm{~g}$ in 60 days a difference of $6.96 \mathrm{~g}$ and from $47.67 \mathrm{~g}$ to $44.04 \mathrm{~g}$ in 90 days a difference of $3.63 \mathrm{~g}$ (Fig 1). It could be observed that there was a continuous weight loss in the course of time. From an initial rapid phase in the first 30 days to a slower phase in the later days. The decay rate coefficient $k$ was worked out to study the constant potential weight loss. The value of $k$ was estimated to be 0.0032 for the $30^{\text {th }}$ day, 0.0039 for the $60^{\text {th }}$ day and 0.0034 for the $90^{\text {th }}$ day.

It was observed that weight loss for the first 30 days in all the treatments was rapid. It was then followed by a slower phase. It was also observed that the $9 y e a r$ stand had the least litter decomposition followed by 7 years and $5 y e a r s$ stands respectively.

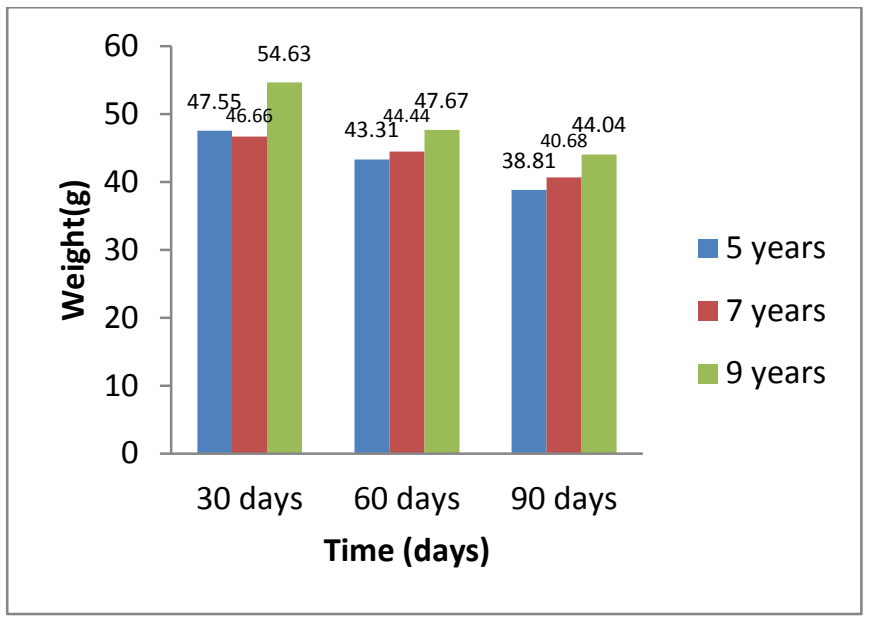

Fig.1: Trends of weight loss (g) with time in decomposing Acacia mangiumleaves in different stand 
Agric. Biol. J. N. Am., 2013, 4(3): 280-283

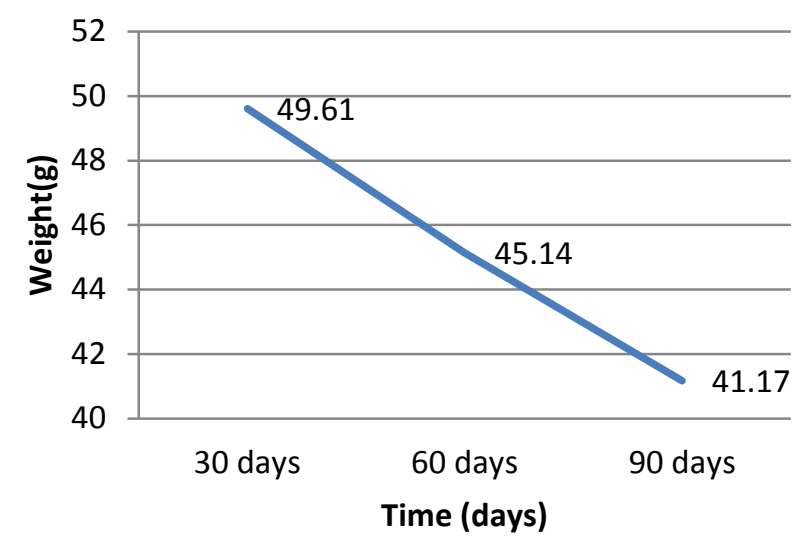

Fig.2: Average trend of weight loss(g) with time in decomposing Acacia mangium leaves

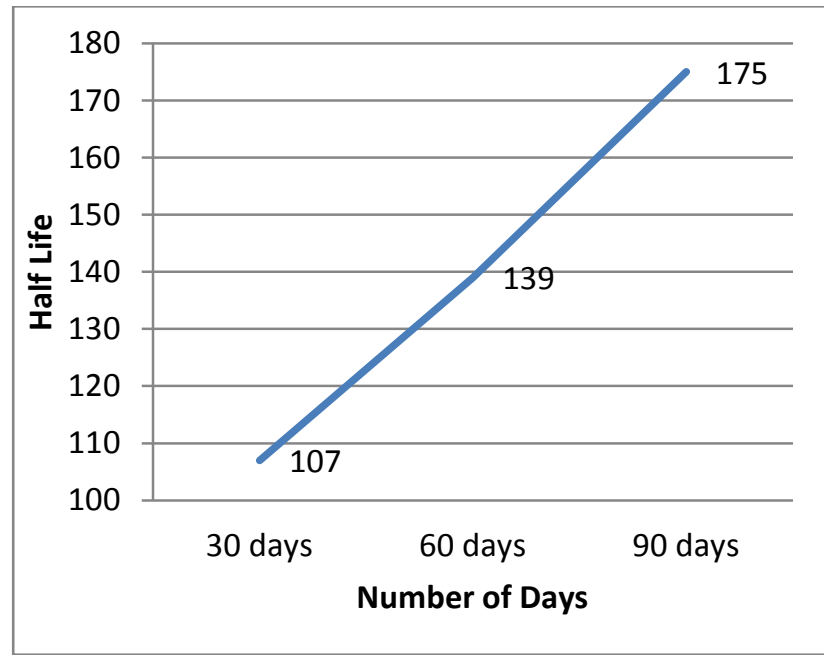

Fig.3: Half-life of Acacia mangium leaf litter

Pattern and mean rate of decomposition: From initial $60.26 \mathrm{~g}$ dry weight to mean dry weight of $49.61 \mathrm{~g}$ in 30 days, $45.14 \mathrm{~g}$ in 60 days and $41.17 \mathrm{~g}$ in 90 days for the stands (Fig. 2). After 90 days of observation, the foliage still contained mean dry weight of $41.17 \mathrm{~g}$ that is $68.32 \%$ of the initial dry matter weight. There was an initial rapid phase of weight loss followed by a slower phase; from initial $60.26 \mathrm{~g}$ to $49.61 \mathrm{~g}$ a difference of $10.65 \mathrm{~g}$, from $49.61 \mathrm{~g}$ to $45.14 \mathrm{~g}$ a difference of $4.47 \mathrm{~g}$ and from $45.14 \mathrm{~g}$ to $41.17 \mathrm{~g}$ a difference of $3.97 \mathrm{~g}$. The decay rate coefficient $\mathrm{k}$ (relative rate of decomposition in a month)was worked out to study the constant potential weight loss. The value of $k$ was estimated to be 0.0064 for the $30^{\text {th }}$ day, 0.0049 for the $60^{\text {th }}$ day and 0.0039 for the $90^{\text {th }}$ day with overall mean of 0.0050 for all the stands. The Half-life (Fig. 3)estimated for all the stands were 140 days which is approximately four and half months. ANOVA at $5 \%$ significant level indicates no significant effect amongst the treatment 5 and 7year stands but significant effect on the 9 years in weight losses on the $30^{\text {th }}$ and $60^{\text {th }}$ but no significant effect between the $60^{\text {th }}$ and $90^{\text {th }}$ day.

\section{DISCUSSION}

Pattern and the rate of decomposition: The Acacia mangium foliage weight loss could be due to a number of factors, including the removal and/or consumption of tissues by leaf-feeding invertebrates, leaching, and biochemical degradation by microorganisms as stated by Wood(1974). The decomposition pattern was biphasic with an initial rapid phase followed by a slower phase. The initial rapid phase could be due to congenial environmental conditions associated with the presence of readily digestible water soluble compounds in the litter. This might have triggered the activity of soil fauna and soil microbes, which are responsible for the decomposition. In addition, the high leaching losses of water-soluble fractions from the decomposing materials during the rainy periods might have resulted in a heavy mass loss during the initial phase. The latter slower phase could be due to absence of congenial condition such as high rainfall and also due to increased content of bio-decay resistant compounds and change in soil fauna responsible for decomposition, which may change with season. This is in agreement with Hegde, (1995) as stated by Sreekalaet al., (2001). The results compares favourably with the work of Sreekalaet al., (2001) who studied decomposition and dynamics of cocoa litter under humid tropical conditions.It is also in agreement with Young, (1997) who studied agroforestry for soil management. In the initial stages ( 0 to 3 months) of leaf breakdown small soluble carbon molecules, like starches and amino acids, are lost first leaving behind the more recalcitrant molecules like lignin as stated by Berg and Staaf, (1980) andMcClaugherty and Berg (1987).

The rate of decomposition of Acacia mangium residue was a function of time of exposure. More than half of the initial weight had not decomposed during the period of study. The half-life of four and half months shows a slower rate of decomposition of Acacia mangium relative to most multipurpose trees. This is also in agreement with Singh et al., (1993) who studied production and decomposition of leaf litter in sal, teak, eucalyptus and poplar forests in 
Agric. Biol. J. N. Am., 2013, 4(3): 280-283

Uttar Pradesh and reported that only three to five months were required for complete decomposition of leaf litter of some important tree species in tropical deciduous forests. Temperature, moisture, and litter chemistry control decomposition rates through their influences on the activity of soil organisms. Forestry activities that influence the microclimate or nature of the litter can alter decomposition rates as stated by Prescott, et al. (2000).

Effects of age on decomposition: The difference in the weight loss between stands might be due to climatic effects on decomposition. The nine year stand has a much closed canopy and might have increased shading effect that might have relatively reduced the temperature of these stands and this does not favour decomposition. Decomposition is mainly a biological process carried out by insects, worms, bacteria, and fungi both on the soil surface and in the soil. Because decomposition is a biological process carried out primarily by bacteria and fungi, its speed is affected by temperature and soil moisture. Generally decomposition increases exponentially with temperature; that is, for every 10 degree rise in temperature, decomposition increases by a factor of two.

It may be due to the fact that lignins, which are complex compounds with 'ring'- type structures are found in older plant tissues and especially woody tissues. They are therefore very resistant to decomposition.

\section{CONCLUSION}

The decay rate coefficients ofthe five-year Acacia mangiumstand were 0.0078 per $30^{\text {th }}$ day, 0.0055 per $60^{\text {th }}$ day and 0.0048 per $90^{\text {th }}$ day. Those for the seven-year stand were 0.0085 per $30^{\text {th }}$ day, 0.0050 per $60^{\text {th }}$ day and 0.0043 per $90^{\text {th }}$ day. The nine-year stand recorded 0.0032 per $30^{\text {th }}$ day, 0.0039 per $60^{\text {th }}$ day and 0.0034 per $90^{\text {th }}$ day. It had been observed that the 9 year stand had the least loss of weight followed by the 7 years and the 5 years stands. This implies that decomposition occurred faster in the younger stands which had more soluble and readily digestible energy rich nutrients in its leaf litter than the older ones which have more lignin and holds complex compounds. This therefore implies that the age and rate of decomposition is inversely related thus the higher the age the lower the rate of decomposition.

\section{ACKNOWLEDGEMENT}

I am thankful to the entire staff of the Environmental Department of the Golden Star Gold Mine Limited of
Bogoso-Prestea for their contributions and support in the area of advice, criticisms and suggestions.

\section{REFERENCES}

Berg, B., and Staaf, H. (1980). Decomposition rate and chemical changes in decomposing needle litter in Scots pine. In T. Persson, (ed.) Structure and function of northern coniferous forests.Ecological BulletinsNFR.32:373-390.

Bunvong, T. and Orman, G. (1978). Climate and the decomposition rate of Tropical Forest litter F.A.O. Corporate Document Repository. Unasylva No.126. Agriculture in Latin America.http://www.fao.org/docrep/n6845e/n6845e05. htm\#TopOfPage. Accessed on $15^{\text {th }}$ November, 2008.

McClaugherty, C. A. and Berg,B. (1987).Celluolose, lignin and nitrogen concentrations as rate regulating factors in late stages of forest litter decomposition. Pedobiologia. 30:101-112.

N.A.S(1979). Tropical legumes: resources for the future. National Academy of Sciences, Washington, DC.

Ngo, V. M and Nguyen, V. H. (1991).Effect of spacing on growth and yield of legume trees on low fertility grey soils in south eastern Vietnam. In: Proceedings of International Symposium on Increasing Livestock Production by Making Better Use of Local Resources in Vietnam (Editors: L V Ly, H T Luu, B Ogle and T R Preston). FAO; Bangkok (In press)

Prescott, C.E. and Blevins, L.L.(2000).Litter decomposition in British Columbia forests: influences of forestry activities. In proceedings, from science to management and back: a science forum for southern interior ecosystems of British Columbia. Pp. 19-21.

Sreekala, N. V., Mercy, G.,Uninthan, V.K.G., John, P.S.,Vikraman, N. R.,(2001).Decomposition Dynamics of Cocoa Litter under Humid Tropical Condition.Journal of Tropical Agriculture 39: 190-192. In: Hegde, R. 1995 Nutrient content and decomposition of leaf litter of Acacia mangiumWilld as affected by season and field conditions, Kerala Agricultural University, Thrissur

Van Cleve, K. (1974).Organic matter quality in relation to decomposition. In: Soil Organisms and Decomposition in Tundra (Holding, A.J.; Heal, D.W.; MacLean Jr., S.F. and Flanagan, P.W., eds.). Swedish IBP Committee, Stockholm, Sweden, pp. 311-324. Vol 17 No1\&2 pp 1116

Wood, T. G. (1974). Field Investigation on the Decomposition of Leaves of Eucalyptus delegatensis in relation to environmental factor. Pedobio., 14: 343371

Young, A. (1997). Agroforestry for Soil management (Second Edition). Published by CAB International/ ICRAF Nairobi Kenya 